\title{
The Effectiveness of Mobile Phone-Based Interventions in Adherence Support for Medication regimens and Immunizations Uptake: A Systematic Review
}

\author{
Onamade, Akintoye Abraham \\ Department of Computer Science and Mathematics \\ Adeleke University \\ Ede, State of Osun, Nigeria \\ PhD Student at University of South Africa, Pretoria \\ E-mail: akin onamade2001@yahoo.com \\ Peter L Mkhize (PhD) \\ Associate Professor \\ School of Computing \\ University of South Africa, Pretoria \\ E-mail: Mkhizpl@unisa.ac.za
}

\begin{abstract}
Mobile phone-based interventions have shown success in support of immunization or medications uptake compliance. A systematic review was undertaken to uncover evidence on the use of mobile phones functions to improve health care process and outcomes. An extensive literature survey was conducted for research studies published between January 2010 and July 2016. Data on mobile phone-based interventions were extracted for the content of mobile phone-based intervention, feasibility, acceptability and health outcomes. It was realised that the deployments of calls and SMS interventions as reminders for clinic appointments, in support of pills intake and in health information delivery are not without challenges.
\end{abstract}

Keywords: SMS, immunization, medications, mobile phone, reminder app

Aims Research Journal Reference Format:

Onamade, A.A. \& Peter, L. Mkhize (2018): The Effectiveness of Mobile Phone-Based Interventions in Adherence Support for Medication regimens and Immunizations Uptake: A Systematic Review. Advances in Multidisciplinary Research Journal. Vol. 4. No. 2, Pp 17-32

\section{INTRODUCTION}

Adherence to medication procedures is a crucial part of diseases control and treatment, particularly for diseases such as diabetes, cardiac, rheumatoid arthritis, vaccines preventable diseases and HIVIAID. Non-adherence to medications regimens for the control and management of deadly diseases by patients has been attributed to forgetfulness, carelessness, misunderstanding of treatment instruction, lack of patient support after discharge, feeling better, or feeling worse (Khonsari et al 2015, Balogun et al 2012). This is evident in World Health Statistics by WHO (2014) that about half of the world's under-five mortality still occurred in only five countries: India, Nigeria, Pakistan, Democratic Republic of the Congo, and China.

Mobile phone as a portable communication device has been instituted as a management tool to enhance information flow between patients and health caregivers to improve health systems. This shows that mobile phone has the potential to support medications regimens and immunization uptakes. Research has also shown that the most frequently used mobile phone functions are calls and text messages (Michelle, et al 2015, Dick et al 2011). Modern functions like web browsing, chat, media and television do not cut across all mobile phone platforms (Tran and Houston 2012). 
Hence, to address dissatisfaction caused by diseases, there have been several mobile phone-based interventions such as short message service (SMS), calls and interactive voice response (IVR) between patients and health caregivers to educate and remind patients of their clinic and immunization appointments, medications taking and procedures (Segaren et al, 2012, Balogun et al, 2012, Michelle et al, 2015, Osborn and Mulvaney, 2013).

Mobile phone-based interventions have been used successfully for improving medication adherence and blood pressure in high-cardiovascular-risk individuals (Patel et al, 2013), self-care tips (Patrick et al 2013, Dick 2011) and reminders to patients with diabetes (Tran and Houston 2012) and Acute Coronary Syndrome (ACS) patients (Khonsari, 2015) with participants reporting a high level of satisfaction with the intervention resulting in improved healthcare and treatment. Overweight adolescents have also endorsed the use of technology to help them with weight-loss efforts (Patrick et al, 2013). Among behavioural health patients, SMS messaging tools are feasible adjuncts to traditional mental treatment in the veteran population (Smith et al, 2012).

Increasing medication adherence through a reminder system is the most common type of behavioural intervention, and one that is intuitively targeted toward patients who forget to take their medication (Patel et al, 2013). Osborn and Mulvaney (2013), state that text messaging could be used to address patientlevel medication barriers because it has the potential to improve health care for vulnerable populations within resource constraints of health systems (Dick et al 2011). Osborn and Mulvaney (2013) identified seventeen (17) barriers to medications adherence. They include: accessing medication(s), believing medication(s) are not important, believing medication(s) are harmful, forgetfulness, lack of belief in the benefits of medication, fear of side effects and so on.

The issues of confidentiality and privacy about the use of mobile phone functions in support of medications taking are connected with willingness to use and this also vary across patients groups. The fear of HIV disclosure was prevalent among AID/HIV patients (Tran and Houston 2012), and stigmatization of veterans with post-traumatic stress disorder or mild traumatic brain injury (Smith et al 2012) inhibited patients willingness to use the service. But in contrast, diabetes patients expressed no privacy concerns in an Urban African-American population of United States and are satisfied and willing to use the service (Dick et al 2011).

Although there is increasing popularity in the use of mobile phone-based interventions in healthcare delivery; the willingness to use and to pay for the services of mobile phone-based intervention varies across patients groups. (Balogun et al 2012, Michelle et al 2015, Patel et al 2013). , a systematic review is required to evaluate their effectiveness on adherence support services with medications regimens and immunizations uptakes.

\subsection{Problems Statement}

In analysing various problems faced by vulnerable populations in rural areas of developing countries, Balogun et al (2012) found out that out of 400 nursing mothers sampled in Nigeria; forgetfulness $(23 \%)$, either mother or child was ill $(22 \%)$, travelled $(20 \%)$, mothers too busy $(16 \%)$ and mixed up dates $(5 \%)$ are some of the reasons why nursing mothers miss clinic appointments. Statistics from WHO (2014) also shows that failure to adopt the internationally agreed standards or best practices relating to immunization and injection safety contributed to vaccines preventable mortality rate in developing countries.

To our knowledge, no systematic review to evaluate the efficacy of mobile phone-based interventions (calls, SMS, web browsing, email, social media and television) on various diseases has been carried out in support of adherence to medication regimens and vaccination uptakes; with a view of generating new model of intervention targeted to addressing specific needs of resource-poor, less educated, illiterate patients living in rural or in areas of low socio-economic status of developing countries. Therefore, system review is necessary in order to uncover new way to use mobile phone functions to improve health care process and outcomes. 


\subsection{Research questions and Research objective}

This review was undertaken to answer the question: Are mobile-based interventions effective in assisting health seekers in ensuring compliance to medication regimens and vaccinations uptakes? This research question is subdivided into:

i) What are the contents of mobile phone-based intervention?

ii) What are the issues that influenced access and the use of mobile phone-based services?

iii) What are the health outcomes of such intervention?

iv) Is there a new way of addressing the problem statement above?

The objective of this research is to systematically review the effectiveness of mobile phone-based interventions in the pursuit of compliance with medications procedures and or immunizations uptakes and to come up with a cost-effective medication reminder modelled-software

\section{RESEARCH METHODOLOGY}

The purpose of this study was to comprehensively and systematically evaluate all the evidences on effectiveness of mobile phone based interventions aimed at improving health conditions of health seekers. Evidences on the issues that influenced access and the use of mobile phone-based services were also reviewed. In this study, the counsel of Kisely et al (2015) was alluded to which states that "avoid being too broad with research question in systematic review as you may be overwhelmed with potential papers". Likewise, a PICOS- acronym was found adequate (Kisely et al 2015). PICOS stands for Population, Intervention, Control, Outcome and Study design. Dorothy (2003) states "What was done to whom under what circumstances with what effect?" is the centre of any systematic review. Hence for this study, the population identified were individuals using mobile phone in support of medications procedures or vaccinations uptakes; the interventions were mobile phone-based strategies (like calling, sending text messages, browsing etc.) and, the outcome was improving health effects on patients who complied with medications regimens and or vaccination uptakes directives.

\subsection{Data Collection}

The data collection and analysis was based on Chitu and Kira (2010) guide on systematic review. This method was selected because it is best suited to evaluate health interventions in diverse settings with multiple interventions and outcomes. As shown in figure I below, the process is divided into: identification stage, screening stage, eligibility stage and inclusion stage. The details of this process and research papers used for this systematic review were explained in section 2.3- Data extraction and Article selection.

\subsection{Search Strategy}

The source of information for this review came from relevant scientific journals from Unisa's library, google and google scholar. This was done by searching online databases like EBSCO HOST (Health source: Consumer Edition, Health Source: Nursing/Academic Edition), SAGE publication and SpringerLink (Computer Science and Communications Dictionary). These databases were searched extensively for all research studies published between January 2010 and July 2016. These dates were selected for currency of the review because "literature on the most recent discourses on the topic and on research methods and designs should preferably not be much older than five years" (MPSET92/DPSET02, 2013). Key search terms such as cell phone, SMS, text message, immunization, mHealth, medications and mobile phones were used. These keywords were found appropriate, chosen and reported because to a larger extent, they brought out useful materials used in this study and they all have links to the topic of discussion. 


\subsection{Data Extraction and Article Selection}

In this review, the main focus was on extracting data on descriptions of interventions (author, year, study design, samples, participants and age), the content of mobile phone-based intervention (the clinical area, study duration, place of research), and issues that influenced access and the use of mobile phone-based services were discussed under findings (feasibility and acceptability, text message content, educational level, limitations of SMS interventions), health outcomes and cost-effective medication reminder modelled-software was synthesized and discussed in section 4.0-Sythensized model.

Inclusion criteria involved studies that had any outcomes using quantitative or qualitative methods on the supportiveness of mobile phone-based interventions for medication procedures, immunization uptakes and issues that have to do with such interventions. The included studies measured health outcomes or processes of care. Inclusion criteria were also extended to studies in a language other than English with full abstract in English language. Studies that evaluated the use of mobile phone-based interventions in others areas were not included.

First, the inclusion and exclusion criteria process started by scrutinising through all the titles of the searched papers (800) to eliminate duplicate (350) studies and to see those that can be excluded based on the title alone; then the abstracts were reviewed and smaller studies were selected. Chitu et al (2010) state that "At this stage, the reviewer normally reads no more than the abstract of the articles to decide whether, for the purposes of the review, they are worth reading further or not". Second, full text titles of the 83 papers were read by two reviewers in order to avoid bias and to maintain objectivity. Third, data were then extracted from 10 studies that met inclusion criteria. In this review, the main focus was on extracting data on descriptions of interventions (author, year, study design, samples, participants and age), the clinical area, study duration, place of research, interventions and health outcomes. Figure 1 shows the flow diagram for this process which adopted PRISMA-Preferred Reporting Items for Systematic reviews and Meta-Analyses (Kisely et al 2015).

After data extraction from the 10 studies, data synthesis was next. At this stage, data were aggregated, discussed, organized and compared in order to come up with a completely polished synthesis of information on the overall assessment of mobile phone-based interventions. Narrative synthesis was adopted here because it allows exploration of relationships across multiple studies. 


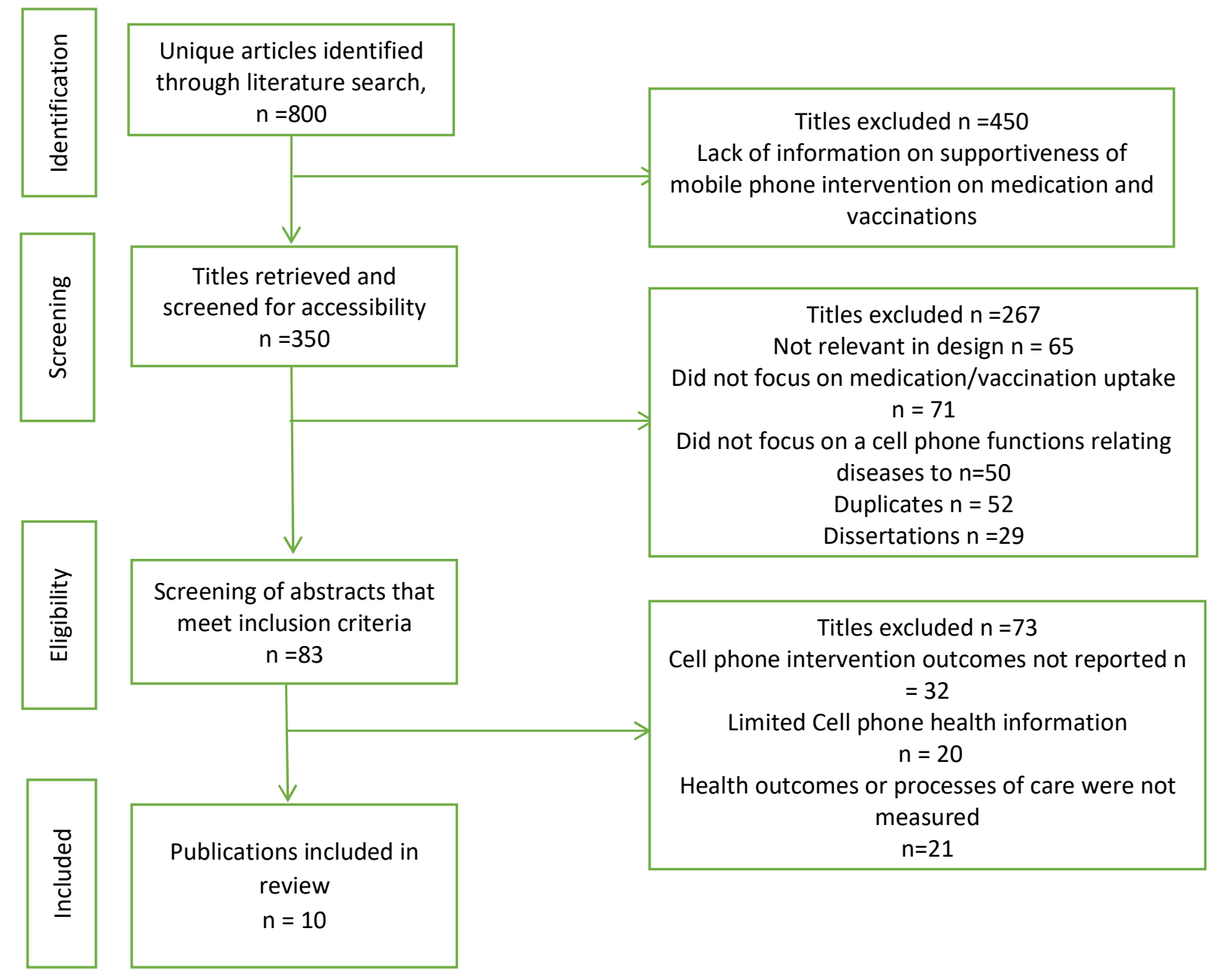

Figure 1: Study selection diagram (Higashi et al, 2013) 
Table 1: Effect of mobile phone-based interventions on medications/immunizations' compliance and health outcomes

\begin{tabular}{|c|c|c|c|c|c|c|c|}
\hline $\begin{array}{c}\text { Author, } \\
\text { (Year) }\end{array}$ & $\begin{array}{l}\text { Study } \\
\text { Design }\end{array}$ & $\begin{array}{c}\text { Sample, } \\
\text { Participants, } \\
\text { age }\end{array}$ & $\begin{array}{c}\text { Clinical } \\
\text { area }\end{array}$ & $\begin{array}{l}\text { Study } \\
\text { Period } \\
\text { (mths) }\end{array}$ & $\begin{array}{l}\text { Place of } \\
\text { Research }\end{array}$ & Intervention & Health outcomes \\
\hline $\begin{array}{l}\text { Tran and } \\
\text { Houston } \\
(2012)\end{array}$ & $\begin{array}{l}\text { Multi-site } \\
\text { cross- } \\
\text { sectional } \\
\text { survey }\end{array}$ & $\begin{array}{l}\text { 1,016, HIV- } \\
\text { positive } \\
\text { patients, } 35.4 \\
\text { years }\end{array}$ & HIVIAID & 3 & $\begin{array}{l}\text { Hanoi, Hai } \\
\text { Phong and } \\
\text { Ho Chi Minh } \\
\text { City in } \\
\text { Vietnam }\end{array}$ & $\begin{array}{l}\text { Reminder to } \\
\text { take pills on- } \\
\text { time by } \\
\text { regular text } \\
\text { messages or } \\
\text { direct calls or } \\
\text { automated } \\
\text { voice calls. }\end{array}$ & $\begin{array}{l}\text { More than three-fourth } \\
\text { of participants }(78.6 \%) \\
\text { considered that using } \\
\text { mobile phone could } \\
\text { be an effective } \\
\text { adherence support } \\
\text { strategy. } 63.5 \% \text { were } \\
\text { willing to use such } \\
\text { additional services if } \\
\text { they were available on } \\
\text { their mobile phone. }\end{array}$ \\
\hline $\begin{array}{l}\text { Khonsari, } \\
\text { Subramanian, } \\
\text { Chinna, } \\
\text { Latif, Ling } \\
\text { and Gholami } \\
(2015)\end{array}$ & $\begin{array}{l}\text { Open- } \\
\text { labelled } \\
\text { randomised } \\
\text { controlled } \\
\text { Trial }\end{array}$ & $\begin{array}{l}62, \text { Acute } \\
\text { Coronary } \\
\text { Syndrome } \\
\text { (ACS) patients, } \\
57.9 \text { years }\end{array}$ & $\begin{array}{l}\text { Acute } \\
\text { Coronary } \\
\text { Syndrome } \\
\text { (ACS) }\end{array}$ & 3 & $\begin{array}{l}\text { Kuala } \\
\text { Lumpur, } \\
\text { Malaysia }\end{array}$ & $\begin{array}{l}\text { Participants } \\
\text { received text- } \\
\text { message } \\
\text { reminders } \\
\text { before every } \\
\text { medication } \\
\text { intake and } \\
\text { received } \\
\text { phone calls } \\
\text { once per two } \\
\text { weeks }\end{array}$ & $\begin{array}{l}\text { The majority of } \\
\text { participants in the } \\
\text { intervention group ( } 29 \\
\text { or } 93.5 \% \text { ) said the } \\
\text { system was useful } \\
\text { and } 64.5 \% \text { felt that it } \\
\text { had helped them in } \\
\text { taking their } \\
\text { medications. } \\
\text { They also perceived } \\
\text { that the system was } \\
\text { supportive and helpful } \\
\text { in preventing } \\
\text { misunderstanding of } \\
\text { their medication } \\
\text { regimen. } \\
\text { Over } 80 \% \text { of } \\
\text { participants requested } \\
\text { for the SMS reminders } \\
\text { to be continued. }\end{array}$ \\
\hline $\begin{array}{l}\text { Dick, Nundy, } \\
\text { Solomon, } \\
\text { Bishop, Chin, } \\
\text { and Peek } \\
\text { (2011) }\end{array}$ & Pilot study & $\begin{array}{l}56, \text { Diabetes } \\
\text { patients, } 55 \\
\text { years }\end{array}$ & Diabetes & 2 & $\begin{array}{l}\text { Chicago, } \\
\text { United State } \\
\text { of American }\end{array}$ & $\begin{array}{l}\text { Automated } \\
\text { text } \\
\text { messages } \\
\text { were sent to } \\
\text { participants } \\
\text { and text } \\
\text { messages } \\
\text { were received } \\
\text { from } \\
\text { participants } \\
\text { on } \\
\text { adherence. } \\
\text { Weekly } \\
\text { telephone } \\
\text { interviews. } \\
\text { In-person exit } \\
\text { interview }\end{array}$ & $\begin{array}{l}\text { Participants strongly } \\
\text { agreed that text } \\
\text { messaging was easy } \\
\text { to perform and helped } \\
\text { with diabetes self- } \\
\text { care. } \\
\text { Missed medication } \\
\text { doses decreased from } \\
1.6 \text { per week to } 0.6 \text { ( } p \\
=.003 \text { ). Patient } \\
\text { confidence in diabetes } \\
\text { self-management was } \\
\text { significantly increased } \\
\text { during and } 1 \text { month } \\
\text { after the pilot ( } p= \\
.002, p=.008) \text {. }\end{array}$ \\
\hline $\begin{array}{l}\text { Osborn } \\
\text { Chandra Y } \\
\text { and Mulvaney } \\
\text { Shelagh A } \\
2013\end{array}$ & $\begin{array}{l}\text { Pilot Study- } \\
\text { MED } \\
\text { Iterative } \\
\text { testing. }\end{array}$ & $\begin{array}{l}\text { 20, Diabetes } \\
\text { patients, } 51.6 \\
\text { years }\end{array}$ & Diabetes & 1 & $\begin{array}{l}\text { Nashville, } \\
\text { Tennessee in } \\
\text { United states } \\
\text { of American }\end{array}$ & $\begin{array}{l}\text { Administration } \\
\text { of barriers to } \\
\text { medication } \\
\text { adherence } \\
\text { assessment } \\
\text { sheet. Then } \\
\text { daily one-way } \\
\text { text message. } \\
\text { Followed by } \\
\text { daily two-way } \\
\text { text message } \\
\text { and IVR calls } \\
\text { after } 2 \text { weeks }\end{array}$ & $\begin{array}{l}\text { In all three rounds, the } \\
\text { majority of participants } \\
\text { provided positive } \\
\text { feedback about the } \\
\text { intervention's features } \\
\text { and content. }\end{array}$ \\
\hline
\end{tabular}




\begin{tabular}{|c|c|c|c|c|c|c|c|}
\hline $\begin{array}{l}\text { Smith. } \\
\text { Harms, } \\
\text { Burres, } \\
\text { Korda, } \\
\text { Rosen, and } \\
\text { Davis (2012) }\end{array}$ & Pilot study & $\begin{array}{l}\text { 27, mTBI or } \\
\text { PTSD patients, } \\
\text { not stated }\end{array}$ & $\begin{array}{l}\text { mTBI or } \\
\text { PTSD }\end{array}$ & 12 & $\begin{array}{l}\text { Northern } \\
\text { California }\end{array}$ & $\begin{array}{l}\text { EMA data } \\
\text { collection via } \\
\text { PDA. } \\
\text { Interactive } \\
\text { text } \\
\text { messaging to } \\
\text { check-in } \\
\text { messages }\end{array}$ & $\begin{array}{l}60 \% \text { found the overall } \\
\text { messaging experience } \\
\text { to be helpful. } 80 \% \\
\text { reported the } \\
\text { affirmation messages } \\
\text { and the buddy } \\
\text { notification of distress } \\
\text { to be helpful and all } \\
\text { participants found the } \\
\text { notification of clinical } \\
\text { staff when a } \\
\text { participant reported } \\
\text { distress through the } \\
\text { system to be helpful. }\end{array}$ \\
\hline $\begin{array}{l}\text { Patel, } \\
\text { Jacobus- } \\
\text { Kantor, } \\
\text { Marshall, } \\
\text { Ritchie, } \\
\text { Kaplinski, } \\
\text { Khurana, and } \\
\text { Katz. (2013) }\end{array}$ & $\begin{array}{l}\text { Pilot study- } \\
\text { sequential } \\
\text { study design }\end{array}$ & $\begin{array}{l}50, \text { Patients } \\
\text { with } \\
\text { hypertension, } 53 \\
\text { years }\end{array}$ & Hypertension & 7 & $\begin{array}{l}\text { Washington, } \\
\text { DC }\end{array}$ & $\begin{array}{l}\text { Provision of } \\
\text { Pill phone } \\
\text { with } \\
\text { medication } \\
\text { reminder and } \\
\text { drug } \\
\text { reference as } \\
\text { part of the } \\
\text { software } \\
\text { package. } \\
\text { Capable of } \\
\text { interactive } \\
\text { text } \\
\text { messages. } \\
\text { Provision of } \\
\text { Educational } \\
\text { material }\end{array}$ & $\begin{array}{l}\text { At study completion, } \\
\text { participants reported a } \\
\text { high level of } \\
\text { satisfaction with the } \\
\text { intervention and } \\
\text { increased medication } \\
\text { adherence by self- } \\
\text { reported survey. } \\
\text { Adherence, as } \\
\text { measured by } \\
\text { pharmacy refill data, } \\
\text { showed a trend } \\
\text { towards improvement } \\
\text { with initiation of the } \\
\text { study and } \\
\text { intervention, and it } \\
\text { declined significantly } \\
\text { after the intervention } \\
\text { was discontinued. }\end{array}$ \\
\hline $\begin{array}{l}\text { Hughes, } \\
\text { Done and } \\
\text { Young (2011) }\end{array}$ & Survey & $\begin{array}{l}112, \\
\text { rheumatology } \\
\text { patients, } 59.5 \\
\text { years }\end{array}$ & Rheumatology & $\begin{array}{l}3 \\
\text { weeks }\end{array}$ & $\begin{array}{l}\text { Hertfordshire, } \\
\text { UK }\end{array}$ & $\begin{array}{l}\text { Email } \\
\text { reminders } \\
\text { SMS } \\
\text { reminders }\end{array}$ & $\begin{array}{l}\text { Email: A large number } \\
\text { responded positively } \\
\text { to an appointment } \\
\text { reminder and about a } \\
\text { quarter of people } \\
\text { would be willing to } \\
\text { receive a medication } \\
\text { reminder. } \\
\text { SMS: Younger } \\
\text { patients are more } \\
\text { open to using SMS as } \\
50 \% \text { of those under } \\
\text { the age of } 65 \\
\text { years would be happy } \\
\text { to receive an SMS } \\
\text { appointment reminder } \\
\text { compared with } 29 \% \text { of } \\
\text { those aged } \\
>65 \text { years. }\end{array}$ \\
\hline $\begin{array}{l}\text { Patrick, } \\
\text { Norman, } \\
\text { Davila, } \\
\text { Calfas, Raab, } \\
\text { Gottschalk, } \\
\text { Sallis, } \\
\text { Godbole and } \\
\text { Covin, (2013) }\end{array}$ & $\begin{array}{l}\text { Randomized } \\
\text { controlled } \\
\text { trial }\end{array}$ & $\begin{array}{l}101, \\
\text { Adolescents at } \\
\text { risk of type } 2 \\
\text { diabetes } \\
\text { mellitus } \\
\text { (T2DM), } 14.3 \\
\text { years }\end{array}$ & $\begin{array}{l}\text { Overweight or } \\
\text { obese }\end{array}$ & 12 & $\begin{array}{l}\text { San Diego, } \\
\text { California }\end{array}$ & $\begin{array}{l}\text { a) Usual care } \\
\text { b) Website } \\
\text { only } \\
\text { c) Website } \\
\text { and follow up } \\
\text { calls } \\
\text { d) Website } \\
\text { and SMS }\end{array}$ & $\begin{array}{l}\text { Baseline quality-of-life } \\
\text { and self-esteem } \\
\text { scores were high and } \\
\text { depression scores } \\
\text { were low and } \\
\text { remained relatively } \\
\text { the same at } 6 \text { and } 12 \\
\text { months, indicative of } \\
\text { good psychological } \\
\text { wellbeing across all } \\
\text { groups and over time, } \\
\text { with positive effects } \\
\text { on sedentary } \\
\text { behaviour }\end{array}$ \\
\hline
\end{tabular}




\begin{tabular}{|c|c|c|c|c|c|c|c|}
\hline $\begin{array}{l}\text { Balogun, } \\
\text { Sekoni, } \\
\text { Okafor, } \\
\text { Odukoya, } \\
\text { Ezeiru, and } \\
\text { Campbell } \\
(2012)\end{array}$ & $\begin{array}{l}\text { Cross- } \\
\text { sectional } \\
\text { study }\end{array}$ & $\begin{array}{l}399, \text { mother of } \\
\text { children less } \\
\text { than } 5 \\
\text { years, } 33.5 \\
\text { years }\end{array}$ & Immunization & 2 & $\begin{array}{l}\text { Lagos, } \\
\text { Nigeria }\end{array}$ & $\begin{array}{l}\text { Assessment } \\
\text { of SMS } \\
\text { reminders in } \\
\text { clinic and } \\
\text { immunization } \\
\text { appointments }\end{array}$ & $\begin{array}{l}\text { About three-quarters } \\
(77 \%) \text { were willing to } \\
\text { receive future SMS } \\
\text { reminders about } \\
\text { childhood } \\
\text { immunizations. } 67 \% \\
\text { preferred telephonic } \\
\text { to SMS and } 53 \% \text { were } \\
\text { willing to pay for the } \\
\text { reminders. }\end{array}$ \\
\hline $\begin{array}{l}\text { van } \\
\text { Velthoven, Li, } \\
\text { Wang, Chen, } \\
\text { Du, Wu, } \\
\text { Zhang, } \\
\text { Rudan, and } \\
\text { Car (2015) }\end{array}$ & $\begin{array}{l}\text { Mixed } \\
\text { method: } \\
\text { survey and } \\
\text { interview }\end{array}$ & $\begin{array}{l}1854, \\
\text { caregivers of } \\
\text { young children, } \\
30.5 \text { years }\end{array}$ & $\begin{array}{l}\text { Mobile phone } \\
\text { in support } \\
\text { health care }\end{array}$ & $\begin{array}{l}\text { Not } \\
\text { given }\end{array}$ & Zhao, China & $\begin{array}{l}\text { The use of } \\
\text { mobile phone } \\
\text { function to } \\
\text { surport health } \\
\text { care in } \\
\text { children }\end{array}$ & $\begin{array}{l}\text { High mobile phone } \\
\text { prevalence and usage } \\
\text { were found which } \\
\text { serve as facilitators for } \\
\text { mHealth based } \\
\text { intervention. }\end{array}$ \\
\hline
\end{tabular}

Note: $\quad$ MED Messaging for Diabetes intervention, IVR Interactive Voice Response, mTBI mild Traumatic Brain Injury, PTSD Post-Traumatic Stress Disorder, EMA Ecological Momentary Assessment, PDA Personal Digital Assistants

\section{FINDINGS}

All 10 studies focused on management, control and treatment of various diseases, ranging from HIV/AID, obesity, acute coronary syndrome, hypertension, diabetes, mental disorder, rheumatology and immunization. 1 focussed on mobile phone-based Antiretroviral adherence support for HIV/AID, 1 measured the effects of website, calls and SMS on promotion of weight loss in adolescents at risk of diabetes, 3 engaged the use of automated medication reminder mobile phones application to monitor the medication adherence of acute coronary syndrome, immunization and hypertension patients, 2 utilized feasibility of text messaging to improve diabetes self-management, 2 used SMS messaging to enhance behavioural health treatment and crisis management in mental treatment. 1 checked SMS and email reminder potential to improve adherence to appointments and medication taking among rheumatology patients.

Randomised controlled trial was adopted by 3 studies (Tran and Houston 2012, Khonsari et al 2015, and Patrick et al 2013). 4 used pilot study design (Dick et al 2011, Osborn et al 2013, Smith et al 2012, and Patel et al 2013,) while 2 used survey (Huges et al 2011, Balogun et al 2012). Intervention duration ranged from 3 weeks to 12 months. 2 studies used one-way text messages as reminders to take pills on time supported with regular calls (Tran and Houston 2012 and Khonsari et al 2015). An automated twoway text messages were sent to participants and text messages were received from participants on adherence by 3 studies (Dick et al 2011, Smith et al 2012 and Patel et al 2013).

Osborn et al (2013) used both one-way text messages and automated two-way text messages supported with interactive voice calls in their studies. Hughes et al (2011) used both email and text messages reminders while Patrick et al (2013) compared the effects of usual care, website only, website with follow up calls and websites with SMS intervention on technology-based intervention to promote weight loss in adolescents. Out of all the studies, only Khonsari et al (2015) had control group and intervention group and only one study was devoted for effect of text messages on childhood immunization. The average ages of the participants ranges from 14.3 to 59.5 years and sample population ranges from 20 to 1,016 participants. The larger percentages of the participants are adults. 6 studies took place in developed countries and 4 in developing countries as shown in Table 1. 


\section{Feasibility and Acceptability}

Many researchers reported that text messages are feasible and useful means to improve health conditions among various groups of patients. Tran and Houston (2012) stated that out of 1,016 participants, more than three-fourth $(78.6 \%)$ considered that using mobile phone could be an effective adherence support strategy. According to Khonsari et al (2015), it was found that $65 \%$ of participants in the intervention group who received SMS - reminders to take medications had a high adherence level compared to only $13 \%$ of those in the usual care group who had low adherence level to take medications. Adherence level is a measure of how many patients are able to complete their medication dosage as at when due. To measure this, patients were asked to complete the eight-item Morisky Medication Adherence Scale (MMAS-8-item). MMAS-8-item is the most useful method in the clinical setting; it is a well-validated self-report questionnaire with good predictive validity to assess medication-taking behaviour and adherence (Khonsari et al 2015).

Likewise, 9 studies reported that people were positive towards and accepted the use of mobile phone intervention strategy (Tran and Houston 2012, Khonsari et al 2015, Dick et al 2011, Osborn et al 2013, Smith et al 2012, Patel et al 2013, Huges et al 2011, Balogun et al 2012 and Patrick et al 2013).

\subsection{Text Messages Content}

The content of text messages sent to patients varies from various patients groups and they depend on the health conditions of the participants that need to be addressed. Questions like "Did you take your diabetes medications today?" and "How many times did you check your feet this week?" is meant to address the problem of daily medication on blood sugar and weekly foot care among diabetes patients (Dick et al 2011, Patel et al 2012). Likewise, a patient faced with cost of medications barriers could be assisted with tailored text messages such as "If you are having trouble paying for your diabetes medications, ask your doctor if there are more affordable medications you could take. (Osborn et al 2013). In another situation, text message content may be used to provide motivational reminders to participants. Smith et al (2012) adopted this strategy in their study to improve health conditions of veterans suffering from mental health such as mild traumatic brain injury and post-traumatic stress disorder. Individualized motivational support messages were adopted which are not limited to the followings; "Be nice to yourself and responsible", "I can do all things through Him who strengthens me", "Remember you are leaving a legacy for your child", "I'm more than a warrior", "Your wife loves your positive attention" and so on. The motivational tailored messages varied widely, from a generic message sent every Friday encouraging weekend relaxation, to very specific reminders that reminded them to think of the individuals who are counting on their recovery, such as 'Remember you are leaving a legacy for your child'.

Also the content of text messaging could be used to harvest periodic assessment of the patients' level of treatment (Smith et al 2012, Osborn et al 2013). Smith et al (2012) used two-text message to conduct 'check ins' in order to support the participant's recovery and provide a periodic assessment of participant's level of distress behavioural health treatment and crisis management. Check -in question such as on a scale of $1-5$, how are you doing overall ? $1=$ Great; $2=$ Good; $3=$ Okay; $4=$ Not good; $5=$ Lousy-Respond and the patients replied with Check-in question response confirmation such as Thank you for your response of [response]

\section{Educational Level}

The level of education of the patients is also associated with type of mobile phone-based intervention. Balogun et al (2012) found out in their study that respondents who were married and had at least a postsecondary education were more willing to receive SMS reminders among mothers of children aged less 5 years brought for immunization in Lagos, Nigeria. This is consistent with studies of Patrick et al 2013, and Khonsari et al 2015, who only recruited participants who had ability to read and write text message in their study. Patel et al (2013) moved ahead in their study to disqualify participants with inability to use a mobile phone or the medication reminder software. Therefore, for effective impact of mobile phone-base intervention, a mobile phone-based application should be designed to reduce the burdens of this vulnerable population in developing countries. 


\section{Limitations of SMS Interventions}

Most of these SMS interventions are specifically targeted on control needs of dwellers of low socioeconomic status living in rural areas (Osborn et al 2013, Balogun et al 2012). The impact of these intervention is laudable but not without some barriers. For instance, phone users may not necessarily be SMS users and this highlights the fact that the ability to communicate via SMS should not be assumed as the decision to reply text messages is influenced by frequency of checking the mobile phone, trusting the sender, emotion or feeling when receiving a text message, clarity of the message, the importance of replying and ease of use of text messages. (Michelle et al, 2015).

Likewise, a high number of mobile phone users use it primarily for calling and receiving calls, while a small proportion of users use it for text messaging (Michelle et al, 2015). Most of the time text messages are not read if they are too many, perceived as unimportant, constitute junks and may be embarrassing, hence they are deleted (Patrick et al 2013 and Michelle et al, 2015).

Therefore, for more effective benefits to be achieved by any SMS intervention as a support for medication regimens and vaccination uptakes, future mobile phone-based intervention should explore the possibility of addressing the aforementioned barriers.

\section{SYNTHESIZED MODEL}

To address the aforementioned barriers in meeting the health challenges of patients living in low socioeconomic areas of the world, there is need to tailor mobile phone intervention with preloaded application to meet their specific needs. This app ("Caring Mother" app) should contain general health information messages specific to ailment to be addressed. It must have audio or visual reminders to take pills and on clinic appointments, and confirmation that these were done.

The contextualization of the synthesized model is captured in Health Belief Model (HBM) of figure 2. The Health Belief Model is a conceptual framework that can be used to guide health promotion and health education programmes. Adopting HBM's decision-making measure, synthesized model posits as a means to communicate to the target population the steps that are involved in taking the recommended action about ailment and highlighting the benefits of that action. The health belief model constructs constitute individual' belief about seriousness or severity of Vaccine Preventable Diseases (Perceived Severity to Disease) in case of immunization uptakes, the greater the perceived personal risk of VPD (Perceived Susceptibility to Disease), the greater the likelihood of engaging in behaviour to decrease the risk; the construct of perceived benefits is a nursing mother's opinion of the value of usefulness of a new behaviour in decreasing risk of developing Vaccine Preventable Diseases (VPD). Nursing mothers tend to adopt healthier behaviours when they believe the new behaviour will decrease their chances of developing vaccine preventable diseases.

The constructs of Health Belief Model is influenced by modifying variables (e.g. education level, culture, past experience etc.,) and cues to action (e.g. "Caring Mother" app, media report, health warning labels, reminder from health professional etc. ) which are events, people or things that move nursing mothers to change their action. 


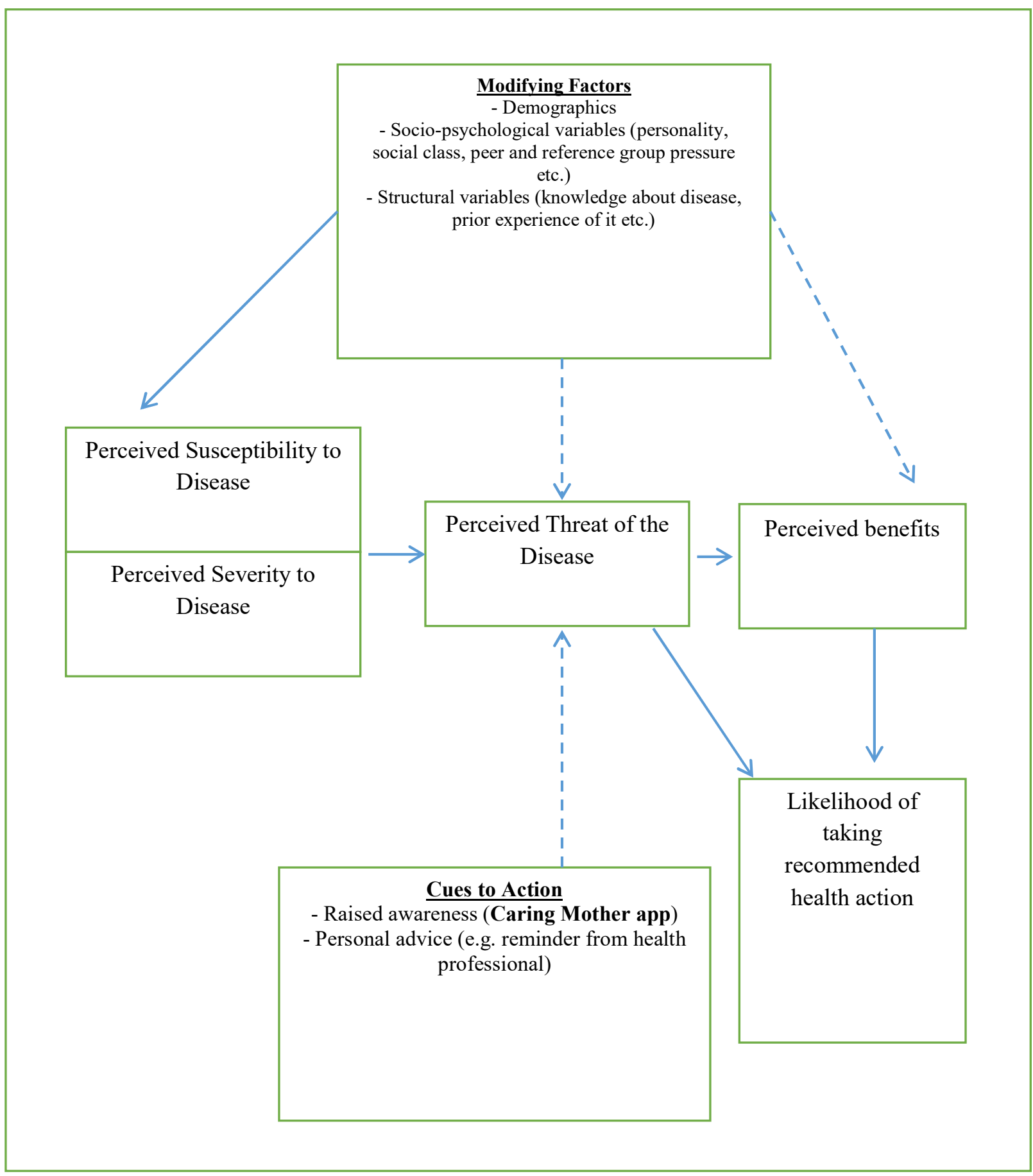

Figure 2: Health Belief Model (Modified from Sharafkhani et al. 2014) 


\section{BACKGROUND TO THE THEORETICAL FRAMEWORK FOR THIS STUDY}

There are many popular predictive models that are widely employed by researchers, professionals and practioners to over explanation on the issues on users' acceptance or adoption of new technology. Such models in the field of Information Systems (IS) are Theory of Reasoned Action (TRA), Theory of Planned Behaviour (TPB), Technology Acceptance Model (TAM), Extended Technology Acceptance Model (TAM2), Unified Theory of Acceptance and Use of Technology (UTAUT) and extended UTAUT (UTAUT 2). Reviewing the models, each of these models had undergone improvement through extensions that led to improved models; the latest of such are UTAUT and UTAUT 2 which are compared in table 2.

Table 2 Summary of comparison of UTAUT and UTAUT 2 Models

\begin{tabular}{|c|c|c|c|}
\hline $\mathbf{S} / \mathbf{N}$ & Model & UTAUT & UTAUT 2 \\
\hline 1 & Authors & $\begin{array}{l}\text { Venkatesh, } \\
\text { Morris, Michael G.; Davis, } \\
\text { Gordon B.; and Davis, Fred } \\
\text { D. }\end{array}$ & Venkatesh V, Thong $\mathrm{J}$ and $\mathrm{Xu} \mathrm{X}$ \\
\hline 2 & Year & 2003 & 2012 \\
\hline 3 & Determinants or constructs & $\begin{array}{lr}\text { Facilitating } & \text { conditions, } \\
\text { influence, } & \text { Perial } \\
\text { expectancy, and } & \text { and Effort } \\
\text { expectancy } & \end{array}$ & $\begin{array}{lr}\begin{array}{l}\text { Price value, Effort } \\
\text { social influence, }\end{array} \quad \text { Hedoncy, } \\
\text { motivation, } & \text { Facilitating } \\
\text { conditions, } & \text { Performance } \\
\text { expectancy, and Habit }\end{array}$ \\
\hline 4 & $\begin{array}{l}\text { Number of determinants or } \\
\text { constructs }\end{array}$ & 4 & 7 \\
\hline 5 & Moderator variables & $\begin{array}{l}\text { Gender, Age, Experience, } \\
\text { and Voluntaries of use }\end{array}$ & Age, Gender and Experience \\
\hline 6 & $\begin{array}{lll}\begin{array}{l}\text { Number } \\
\text { variables }\end{array} & \text { of moderator } \\
\end{array}$ & 4 & 3 \\
\hline 7 & Focus & Organization context & Consumers context \\
\hline 8 & Sources of the model & $\begin{array}{l}\text { Based on hybrid of eight } \\
\text { models }\end{array}$ & $\begin{array}{lll}\begin{array}{l}\text { Based or improvement } \\
\text { UTAUT }\end{array} & & \\
\text { UTA }\end{array}$ \\
\hline 9 & Explanatory power & $\begin{array}{l}\text { Better than TAM and TAM2 } \\
\text { (Behavioural intention= } 56 \% \\
\text { Technology Use }=40 \% \text { ) }\end{array}$ & $\begin{array}{l}\text { Substantial or better } \text { than } \\
\text { UTAUT } \\
\text { (Behavioural intention= } \\
\text { Technology Use }=52 \% \text { ) }\end{array}$ \\
\hline 10 & Monetary cost & Bears by organization & Bears by consumer \\
\hline 11 & $\begin{array}{l}\text { Use and acceptance of } \\
\text { technology }\end{array}$ & Mandatory & Voluntary \\
\hline
\end{tabular}

The theoretical model for this study is Extended Unified Theory of Acceptance and Use of Technology Model (UTAUT2). This model is chosen to take into account the particularity of the consumer use context in explaining the use and acceptance of the proposed synthesized model. The appropriateness of this choice is also justified by characteristics of UTAUT2 (table 2). This model is an information system theory that models how user - a consumer comes to use and accept a new technological innovative. This suggests that whenever users come across new technological innovative, difference issues inform the users about when and how to adopt the new application (Mohamed et al, 2012). 


\section{DISCUSSION AND RECOMMENDATIONS}

There are dearth research studies on the role of social media like WhatsApp, Facebook and twitter on adherence to medication procedures and immunization uptakes among the patients within the health systems. These smartphone applications have the potential to impact health promotion, process of care and control of diseases at cheaper rate than SMS interventions. Thus, there is the need for more studies that identify and evaluate the evidences of effectiveness and cost effectiveness of smartphonemessaging applications in healthcare.

It was clear from the papers reviewed that each function of the mobile phone-based intervention was used as a complement of each other in diseases control and management. Patrick et al (2013:4) used calls with repeated email to remind the participants to complete their web tutorials on intervention to promote weight loss and healthy behaviours among adolescents at risk of type 2 diabetes mellitus. Khonsari, et al (2015) also supplemented text-message reminders with phone calls on medication intake in the management of Acute Coronary Syndrome (ACS) in Kuala Lumpur, Malaysia. Interactive text messaging to check-in messages were supported with calls in the treatment process of hypertension (Patel et al 2013), diabetes (Osborn et al 2013), mild Traumatic Brain Injury (mTBI) or Post-Traumatic Stress Disorder (PTSD) among veterans (Smith et al 2012). Most health seekers prefer receiving information through text messaging, followed by direct calls by health workers and automated voice calls (Tram and Hoston 2012).

The interactive two-way text messaging technology developed by Smith et al (2012) and Osborn et al (2013) in which patients check-in messages on their personal cell phones to provide a periodic assessment of their level of adherence are laudable. However, the small sample data used in the above studies; 26 and 20 respectively may be an indication that such interventions are expensive to implement in large population surveys. There is need to move beyond short-term study of the impact of the mobile phone interventions to long-term because most of the research health outcomes in this review work came from three weeks to twelve months study durations.

\section{CONCLUSION}

To close gaps that exist in getting good health care between low income and high income countries, rural and urban dwellers, innovative services which can support and give new approach to the delivery of health care services are necessary. Thus, a mobile phone-based medication reminder app shows promise in addressing patient-level medication barriers, vaccination uptakes and improve adherence within the vulnerable populations.

The anticipated benefits of new mobile Apps derived from these review are: The mobile application requires only one time installation on user phone. Audio/visual prompts or reminders include voice messages or short video clip of health caregiver assigned to the patient (for instance explaining to them their next clinic appointment or prescribing medications for them as the case may be) stored or hosted on their mobile phone which their mobile phone can play on schedule as reminder.

The illiteracy level of the patient is taken care of by the strategy mentioned above which may be programed and deployed in the language of choice. The model will be cost effective as the all reminders including health messages are generated from user phone, which removes the possibility of deleting or ignoring the messages as every action will be captured by the software. The problem of not having call card is also addressed because it does not require any except when stored responses are required to be transmitted occasionally for further processing. The application is absolutely free as it requires no form of payment or subscription once it is installed.

Patients with some kind of disabilities can also benefit from the model. Patients who are blind can make use of voice message or sound of video clips and the deaf can make use of video clips and SMS message. 
The only foreseen challenges of this new model are: i) compatibility with various Operating System (OS) especially with low end phones which may be common among patients living in area of low socioeconomic level. ii) Irregular supply of electricity to charge the mobile phones in some rural communities could also pose a barrier to the new model.

\section{DIRECTION FOR FUTURE WORK}

There is possibility that the researcher could have unexploited other elements or factors that could have been used to develop the deliverable of this study; therefore, more investigations are required to promote a lifestyle change towards improving immunization adherence by leveraging on emerging innovative platform available on mobile phone-based interventions. 


\section{REFERENCE}

1. Abdul Hakim H. M. Mohamed, Hissam Tawfik, Lin Norton and Dhiya Al-Jumeily 2012, Does eHealth technology design affect $\mathrm{m}$-Health informatics acceptance? A case study. Proceedings of the IEEE-EMBS International Conference on Biomedical and Health Informatics (BHI 2012) Hong Kong and Shenzhen, China, pp. 968-971.

2. Balogun M.R, Sekoni A.O, Okafor I.P, Odukoya, O.O, Ezeiru, S.S, Campbell P.C (2012). Access to information technology and willingness to receive text message reminders for childhood immunisation among mothers attending a tertiary facility in Lagos, Nigeria. SA Journals of Child Health. S Afr J CH 2012; 6(3):76-80.DOI:10.7196/SAJCH.439.

3. Chitu O. and Kira S. (2010). A Guide to Conducting a Systematic Literature Review of Information Systems Research. Sprouts. ISSN1535-6078.

4. Dick J. J, Shantanu N, Marla C. S, Keisha N. B, Marshall H. C, and Monica E. P (2011). Feasibility and Usability of a Text Message-Based Program for Diabetes Self-Management in an Urban African-American Population. Journal of Diabetes Science and Technology. 5(5).

5. Dorothy A. F. (2003). An Example of the Use of Systematic Reviews to Answer an Effectiveness Question. Western Journal of Nursing Research, 2003,25(2),179-192

6. Higashi K, Goran M, Kavi J. L, Teresa D, Ola G and Marc De Hert (2013) Medication adherence in schizophrenia: factors influencing adherence and consequences of nonadherence, a systematic literature review. Therapeutic Advances in Psychopharmacology. (2013) 3(4) 200218, http://www.sagepub.co.uk/ journalsPermissions.nav

7. Hughes L. D, John D and Adam Y. (2011). Not 2 old 2 TXT: There is potential to use email and SMS text message healthcare reminders for rheumatology patients up to 65 years old. Health Information Journal 17(4) 266-276.

8. Karin H., and Laurence C. (2007). Learn to Read and Write Systematic Reviews: The Belgian Campbell Group. Research on Social Work Practice, Vol.17 No. 6, November 2007 748-753. DOI: $10.1177 / 1049731507303106$. Sage Publications

9. Khonsari S., Pathmawathi S., Karuthan C., Lydia A. L., Lee W. L. and Omid G. (2015). Effect of a reminder system using an automated short message service on medication adherence following acute coronary syndrome. European Journal of Cardiovascular Nursing. 14(2), 170-179. DOI: 10.1177/1474515114521910. cnu.sagepub.com.

10. Kisely S., Alice C., Jim C., Cherrie G., Peter J., Samantha L., Jeffrey C L., Matthew D. M,, Ness M., Stephen P., Brian P., Dan S., Geoff S., Sally M. and Stephen M. (2015).Getting started in research: systematic reviews and meta-analyses Australasian Psychiatry 2015, 23(1) 16 -21. DOI: $10.1177 / 1039856214562077$. apy.sagepub.com

11. Michelle H. V, Ye Li, Wei W., Li C., Xiaozhen D., Qiong W., Yanfeng Z., Igor R., Josip C. (2015). Prevalence of Mobile Phones and Factors Influencing Usage by Caregivers of Young Children in Daily Life and for Health Care in Rural China: a mixed methods study. PLOSONE|DOI:10.1371/journal.pone.0116216

12. MPSET92/DPSET02 (2013). Research Proposal for Master's in Computing and Doctoral in Information Systems and Computer Science. School of computing, University of South Africa

13. Okoli, C., Schabram, K. (2010). A Guide to Conducting a Systematic Literature Review of Information Systems Research. Sprouts: Working Papers on Information Systems, 10(26). http://sprouts.aisnet.org/10-26

14. Osborn C. Y. and Mulvaney S. (2013). Development and Feasibility of a Text Messaging and Interactive Voice Response Intervention for Low-Income, Diverse Adults with Type 2 Diabetes Mellitus. Journal of Diabetes Science and Technology. 7(3).

15. Patel S., Laura J., Lorraine M., Clark R., Michelle K., Parvinder S. K., and Richard J. K. (2013). Mobilizing Your Medications: An Automated Medication Reminder Application for Mobile Phones and Hypertension Medication Adherence in a High-Risk Urban Population. Journal of Diabetes Science and Technology. 7(3). 
16. Patrick K., Gregory J. N., Evelyn P. D., Karen J. C., Fred R., Michael G., James F. S., Suni G. J R. C., (2013). Outcomes of a 12-Month Technology-Based Intervention to Promote Weight Loss in Adolescents at Risk for Type 2 Diabetes. Journal of Diabetes Science and Technology 7(3)

17. Segaren N, Lewis T, Desinor O, Simeon E and Segaren N. (2012). The distribution and use of cell phones to mothers of HIVpositive infants identified by the Haiti National Early Infant Diagnosis of HIV program (EID): a model for increasing adherence? Abstracts of the XIX International AIDS Conference. Journal of the International AIDS Society 2012, 15 (Suppl 3): 236287. From http://www.jiasociety.org/index.php/jias/article/view/18443 (accessed 9 May 2013)

18. Sharafkhani Naser, Mahboobeh Khorsandi, Mohsen Shamsi, and Mehdi Ranjbaran 2014. Low Back Pain Preventive Behaviors Among Nurses Based on the Health Belief Model Constructs. DOI: 10.1177/2158244014556726, October-December 2014: 1-7, sgo.sagepub.com

19. Shaw R. and Bosworth (2012) Hayden Short message service (SMS) text messaging as an intervention medium for weight loss: A literature review. Health Informatics Journal 18(4) 235250.

20. Smith B., William D. H., Stephanie B., Holly K., Howard R., Jamie D. (2012). Enhancing behavioural health treatment and crisis management through mobile ecological momentary assessment and SMS messaging. Health Informatics Journal. 18(4) .pp 294-308.

21. Tran B. X. and Houston S. (2012) Mobile Phone-Based Antiretroviral Adherence Support in Vietnam: Feasibility, Patient's Preference, and Willingness-to-Pay. Published online: 20 July 2012 (c) Springer Science Business Media, LLC 2012

22. World

Health

Statistics

(2014).

From http://www.who.int/gho/publications/world_health_statistics/2014/en/ (accessed April 27, 2015) 